\title{
Some Sources of Technological Novelty: An Essay
}

\author{
Carroll Pursell
}

The Australian National University

Abstract: By the end of the eighteenth century, the unfolding Industrial Revolution was seen to be based, in large part, on a rapidly evolving technological base. At the same time, the source of these innovations was thought to be the work of a new social type: the inventor. For a long century this font of change was encouraged by both public policies and cultural celebration. By the beginning of the twentieth century, however, the growth of industrial corporations and the increasing power of science to predict and control natural processes had led to the eclipse of the 'lone' inventor and the rise of teams working in industrial research laboratories. The inventor lived on for a time as a semi-comic figure in popular culture but no longer as a popular folk hero.

Mark Twain's tale A Connecticut Yankee in King Arthur's Court tells the story of a Hartford mechanic who attempted to reproduce American government and technology in sixth-century England; it was a classic effort at modernisation-what some scholars might now call an example of the Enlightenment Project. When he took over the kingdom and titled himself 'Sir Boss', he related:

\begin{abstract}
The very first official thing I did, in my administration —and it was on the very first day of it, too-was to start a patent office; for I knew that a country without a patent office and good patent laws was just a crab, and couldn't travel any way but sideways or backwards. ${ }^{1}$
\end{abstract}

A few years before, the future president, Abraham Lincoln, then an Illinois attorney who handled patent cases and held one himself, proclaimed that the Patent System ... added the fuel of interest to the fire of genius in the discovery and production of new and useful things'. ${ }^{2}$ So powerful and

Mark Twain, A Connecticut Yankee in King Arthur's Court (New York: Signet Classics, 1963), 58.

2 'Second Lecture on Discoveries and Inventions', Collected Works of Abraham Lincoln, vol. 3, accessed 24 June 2019, quod.lib.umich.edu/l/lincoln/lincoln3/1:87? rgn=div1; view=fulltext. 
widespread has this belief become that, in 2018, the United States Patent Office issued patent number 10 million while, in the previous year alone, China had granted 1.8 million patents. ${ }^{3}$

Gyro Gearloose, Walt Disney's cartoon inventor, is popular in Brazil, where he is known as 'Professor' Gearloose. The honorific is undeserved but significant. Brazilians explain that, since Gyro is an inventor, and inventions come out of scientific research, and scientific research is done in universities, he obviously is a professor. In the American original, however, Gearloose is an 'independent' inventor, so impractical that he must tie his hat on his head or lose it. While his inventions always do something, they never do exactly what he intends. In contrast to Walt Disney's evil scientist Dr Kronos, who works for illegitimate power (the criminal Mr Big), Gearloose often works for legitimate power, the fabulously wealthy capitalist, 'Uncle' Scrooge McDuck.

That simple premise, and its Brazilian variation, tell us a great deal about the popular beliefs that surround inventors. First, inventions do not come from nowhere; they come from someone. Second, inventors need support from somewhere. It is (and always has been) an expensive and complicated process to move from an idea to a product. The inventor is seldom 'alone'. ${ }^{4}$ Third, nothing has only one use, and even the inventor is not always the best person to predict the possibly many ways in which an invention might be used. Surprises are always to be expected. Fourth, inventors in our own time have acquired a reputation for, at the very least, eccentricity and, at the extreme, a kind of madness. Finally, the perception of where inventions come from shifted in the last century from the individual genius to the trained expert, usually working in a scientific laboratory that is a part of some larger, usually corporate or government, organisation.

Gyro Gearloose's eccentricity and lack of institutional attachment point to one final truth: often, new products, processes and attitudes must come from outside the status quo. Marginality, defined in any one of a number

3 'Patents Through History', United States Patent and Trademark Office, accessed 24 June 2019, 10millionpatents.uspto.gov; Lulu Yilun Chen, 'China Claims More Patents Than Any CountryMost Are Worthless', Bloomberg, 27 September 2018, accessed 21 June 2019, www.bloomberg.com/ news/articles/2018-09-26/china-claims-more-patents-than-any-country-most-are-worthless.

4 See Carroll Pursell, 'The American Patent Agency: The Embedded "Lone Inventor" in American History', Icon 17 (2011): 31-39. 
of ways, is not always a bad quality in an inventor: outside the industry or firm, outside the academy or court, outside the standards of bourgeois respectability, ignorant, perhaps, of accepted practice.

Three myths misinform our notions of the source of invention. The first of these, and the most difficult to refute because it is based on a semireligious faith in the inevitability of progress, is the belief that technology comes out of its own logic, inevitably and irresistibly. This view is neatly summed up in the truism that if it can be done, it will be done'. The notion is that a kind of invisible hand guides technology ever onward and upward, using individuals and organisations as vessels for its purposes but guided always by a sort of divine plan for bringing the greatest good to the greatest number. Ever since the battle of the ancients and the moderns, technological improvement has, perhaps, been the best evidence for progress in this otherwise disappointing world, where virtue and wisdom seem no further along than they were two millennia ago.

Stripped of its mystical faith, however, the proposition can best be tested by the citation of technologies that, while possible, are still not widely in use. Passive solar design of buildings, for example, goes back at least as far as the ancient Greeks, but even now is resisted as exotic and somehow futuristic. Active solar devices, like those for heating water, were commercially available in the United States in the late nineteenth century and widely used in Southern California early in the twentieth century. ${ }^{5}$ They too, however, are widely considered untested and possibly practical only sometime in the future. Solar voltaics, the direct conversion of sunlight into electricity, is increasingly used today, but receives only a small fraction of the research and development attention that is lavished on such truly speculative power sources as laser fusion. There are no doubt a number of reasons why all this is so, but the fact remains that, while all these kinds of solar technology 'can' be done, they are only recently being adopted on a large scale.

A second myth is summed up by the saying 'necessity is the mother of invention'. One commentator has charged that, in fact, the 'reality, more often than not, is almost exactly the reverse: Invention is the mother of necessity'. Not only were some inventions not 'needed', but also they may have been absolutely rejected by society when they first appeared.

5 Ken Butti and John Perlin, A Golden Thread: 2500 Years of Solar Architecture and Technology (New York: Van Nostrand Reinhold Co., 1980). 
Often this rejection comes from manufacturers who see no reason to introduce 'better' ways of doing whatever their regular products do already. Other times, manufacturers market the inventions but nobody buys. The telephone with a small television screen, allowing speakers to see each other, was a resounding failure when it was first introduced, though today's smart phones are a rethinking of this old idea.

The parking meter usefully demonstrates the complexity of the idea that inventions respond to 'needs'. In 1993, the city of San Francisco was home to 464,100 vehicles, constituting a density of 10,313 vehicles per square mile of city. The city also had 21,000 parking meters. Why were they there? One can imagine that, originally, some inventor 'needed' to make an invention, because that is the way they make a living. The devices themselves, clever and straightforward combinations of clocks and coin-operated vending machines, are manufactured by firms that 'need' products to sell.

The city of San Francisco 'needs' the revenue produced, although the $\$ 10,891,000$ raised in $1991-92$ was partially offset by the $\$ 5-6$ million spent to repair vandalised machines and in lost revenue. Local merchants 'need' the meters to keep some motorists, perhaps commuters, from taking up the space in front of their shops for the entire day, and shoppers 'need' them so that, after several futile circles of the block, they may eventually find a place to park their cars. ${ }^{6}$

Many of these 'needs', of course, derive from the fact that people drive cars rather than walk or use public transport, and all these needs could be met some other way besides using parking meters. Many modern 'needs' are themselves inventions, the product of an economy that stimulates consumption so that it can make and market things for profit. ${ }^{7}$ To dignify these with the term 'needs' is simply to obscure rather than explain where inventions come from. The word 'need' carries vague implications of inevitability, and its 'filling' by business seems tinged somehow with public service.

'Inventiveness', the historian Brooke Hindle has written, 'was, of course, responsive to needs, but it often looked for the need after a possible invention had arisen in the mind'. With organic evolution, he concluded:

6 San Francisco Chronicle, 26 May 1993.

$7 \quad$ For an excellent example, see Robert Friedel, Zipper: An Exploration in Novelty (New York: W. W. Norton, 1994). 
Positive mutations are selected for perpetuation; just as inventive ideas may be selected for development when they prove applicable to social and economic needs-or even when such needs can be aroused. ${ }^{8}$

The third presumed source of invention is the classic inventor: a 'genius' who, like the Romantic artist, draws on springs of creativity both noble and mysterious. This idea is firmly entrenched in popular culture and, in 1941, became a part of American patent law through the concept of the 'flash of genius' that legally defines the moment of inspired design, as opposed to mere tinkering or technical skill. Like the artist too, inventors have often been seen as misunderstood dreamers, half mad perhaps, thriving in isolated workshops and sometimes rewarded only long after their deaths.

The inventor as a social type appeared only in the eighteenth century. For millennia, technological change had been slow and anonymous: the truly great inventions such as the wheel and the corn mill, have no names, or even dates, attached to them. In part this was because, while science had always been associated with the court and church, practised by learned scholars often known to history, new technologies arose from humble workers and artisans, usually illiterate and socially anonymous.

Beginning with the Industrial Revolution, such names as Newcomen and Watt, Arkwright and Cort leap from the accounts of industrial progress as people who, through their individual genius and perseverance, created tools, machines and processes that had not existed before. The nineteenth century, of course, was the great age of heroes, and romantic notions of genius were grafted onto an older Renaissance celebration of the individual. This was especially true in America, which bragged that its national heroes were not kings, generals and demented religious leaders who gained a place in history through conquest, destruction, cruelty and similar villainies, but simple inventors, risen from the people to bring great benefits to the people.

The scientific study of genius flourished in the nineteenth century, allowing one enthusiast to claim in 1896 that:

8 Brooke Hindle, Emulation and Invention (New York: New York University Press, 1981), 128. 
Looking at this campaign of progress from an anthropological and geographic standpoint, it is interesting to note who are its agents and what its scenes of action. It will be found that almost entirely the field [of invention] lies in a little belt of the civilized world between the 30th and 50th parallels of latitude of the western hemisphere and between the 40th and 60th parallels of the western part of the eastern hemisphere, and the work of a relatively small number of the Caucasian race under the benign influences of a Christian civilization.?

Of the idols of Anglo-American Victorian culture, only capitalism was unacknowledged. Not surprisingly given the times, these paragons were assumed to be white males. No doubt most were, but it is also true that women, and in the United States African Americans, struggled for acknowledgement of their inventive activities as well. ${ }^{10}$

In fact, rather than paragons of Victorian virtue and respectability, inventors often turned out to be misfits, ill-suited to polite society. The Massachusetts Institute of Technology historian Elting Morison reported that, of some 30 or so nineteenth-century inventors he once studied informally:

A surprising number turned out to be people with little formal education, who drank a good deal, who were careless with money, and who had trouble with wives or other women. ${ }^{11}$

The out-of-control masculinity in this description is palpable. If indeed inventors exhibited these characteristics more commonly than other men of their time (which may or may not be true), then perhaps Morison is correct in suggesting that we can:

Look upon invention as a hostile act-a dislocation of existing schemes, a way of disturbing the comfortable bourgeois routines and calculations, a means of discharging the restlessness with arrangements and standards that arbitrarily limit. ${ }^{12}$

9 Edward Byrn quoted in Robert Friedel, 'Perspiration in Perspective: Changing Perceptions of Genius and Expertise in American Invention', in Inventive Minds: Creativity in Technology, ed. Robert J. Weber and David N. Perkins (New York: Oxford University Press, 1992), 16.

10 For women see, for example, Carroll Pursell, 'Women Inventors in America', Technology and Culture 22 (July 1981): 545-49, doi.org/10.2307/3104389. For African American inventors, see Carroll Pursell, ed., A Hammer in Their Hands: A Documentary History of Technology and the AfricanAmerican Experience (Cambridge: MIT Press, 2005), especially 165-73.

11 Elting E. Morison, Men, Machines, and Modern Times (Cambridge: MIT Press, 1966), 9.

12 Morison, Men, Machines, and Modern Times, 9. 
If it all sounds now a bit bohemian, we should remember that the words 'artist' and 'artisan' have a common root in the Latin word ars, suggesting the two share common traits.

In the spring of 1993, newspapers reported that 'a British inventor has stunned military and scientific experts by creating a plastic tough enough to withstand heat from nuclear explosions'. Perhaps it was the physical properties of this 'variety of 21 polymers, copolymers, ceramic and additives' that 'stunned' the experts, but just as surely their surprise sprang in part from the fact that the inventor, one Maurice Ward, was said to be a businessman and 'a former hairdresser with no university training'. ${ }^{13}$ One thinks of that other hairdresser, Richard Arkwright, whose eighteenth-century water frame was a key invention in the shift from hand to power spinning in the transformation of the textile industry. Like those who find it difficult to believe that Shakespeare could really have written his plays, doubters often are 'stunned' to find new ideas coming from inappropriate sources-from people too far outside the loop. And that collective of inappropriate sources could be defined in many ways.

Engineers were often inventors as well, designers of the new machine society, and they too came to prominence as civil builders first in the eighteenth century. The first generation or two made up what historian R. A. Buchanan has called 'a motley crew'. Most of them, he points out, 'were artisans, practical craftsmen from humble homes and lacking in any formal education, although many of them had served apprenticeships as millwrights, mechanics, instrument makers, or stonemasons ${ }^{\prime} .^{14}$

We are informed by Samuel Smiles that the great James Brindley, a member of the first generation of British civil engineers:

Could scarcely read, and he was thus cut off, to his own great loss, from familiar intercourse with a large class of cultivated minds, living and dead; for he could not share in the conversation of educated men, nor enrich his mind by reading the stores of experience found treasured up in books. Neither could he write, except with difficulty and inaccuracy. ${ }^{15}$

13 (Cleveland) Plain Dealer, 2 May 1993.

14 R. A. Buchanan, 'Gentlemen Engineers: The Making of a Profession', Victorian Studies 26 (Summer, 1983): 410-11.

15 Samuel Smiles, Selections from Lives of the Engineers, with An Account of Their Principal Works, ed. Thomas Parke Hughes (Cambridge: MIT Press, 1966), 166. 
It was perhaps for this reason that, according to his brother-in-law:

When any extraordinary difficulty occurred to Mr. Brindley in the execution of his works, having little or no assistance from books or the labours of other men, his resources lay within himself. In order, therefore, to be quiet and uninterrupted whilst he was in search of the necessary expedients, he generally retired to his bed; and he was known to be there one, two, or three days, till he had attained the object in view. He would then get up and execute his design, without any drawing or model. Indeed, it was never his custom to make either, unless he was obliged to do it to satisfy his employers. ${ }^{16}$

These stories about Brindley, albeit filtered through the imagination of the nineteenth century's preeminent celebrant of technical genius, are revealing in several ways. Like many inventors, he was a person of humble origins and limited formal education, more comfortable communing with things than with people, and at his best when withdrawn from social interaction and distraction. The historian Thomas Hughes, in sketching the characteristics of independent inventors at the turn of the twentieth century, observes that:

Aware of the unorthodoxy of their ideas, inventors and [avantgarde] artists intensified their feelings of being outsiders by their physical withdrawal. Working in their retreats, intellectual and physical, they created a new way, even a new world, to displace the existing one. ${ }^{17}$

This trope of isolation has often been invoked by authors when they have dealt with inventors. In the Capek brothers' play R.U.R., the invention, development and manufacture of robots take place on an unidentified island far from Europe and the markets for their machines. In Franz Kafka's story The Penal Colony, the terrible and complicated machine for bringing enlightenment and death to offenders is designed, constructed and used in a typically Kafkaesque landscape that, while nowhere, could be anywhere. In the film Things to Come, based on the H. G. Wells novel, scientists and engineers withdraw from England to an isolated island after a great world war, there to design and build a great air armada capable of recapturing the country from the barbarian hordes that roam its blighted landscape.

16 Quoted in Smiles, Selections from Lives of the Engineers, 168.

17 Thomas P. Hughes, American Genesis: A Century of Invention and Technological Enthusiasm, 1870-1970 (New York: Viking, 1989), 24. 
Besides the desire for isolation, the other striking element in the Brindley story is his ability to visualise his technical problems and their solutions, to the extent, even, that he had no need to make drawings or models. Again, the classic stories of inventors often emphasise this same element. The Romanian-American inventor Nikola Tesla claimed that he could design, test, alter and perfect a new device entirely in his visual imagination, so that the resulting machine, when built, would operate perfectly. Robert Fulton, 'father' of the steamboat, was an artist by training, and Samuel F. B. Morse, inventor of the electric telegraph, was a professor of art in New York City.

Whether these inventors drew more on the right hemisphere of the brain (seat of visual, auditory and tactile inputs) than from the left (which handles speech and mathematics), Hindle has pointed out that they drew upon their artistic talents and training to enable them to choose among numerous design solutions. Further, it was a distinct advantage to be able to picture spatially the way in which design components might be put together in systems - that is, how they could be connected. The 'contriving mind' is the characterisation Hindle put upon this configuration of advantages. ${ }^{18}$

Eugene Ferguson, a mechanical engineer turned historian, studied a similar advantage among the great engineers of the past. He maintains that:

Until the 1960s a student in an American engineering school was expected by his teachers to use his mind's eye to examine things that engineers had designed-to look at them, listen to them, walk around them, and thus develop an intuitive 'feel' for the way the material world works and sometimes doesn't work. ${ }^{19}$

The ability to 'see' with the 'mind's eye' is being lost, Ferguson fears, with the result that the art of design (perhaps in invention, as well as engineering) is losing out to a mindless dependence on mathematics and computer models. 'Nearly all engineering failures', he warns, 'result from faulty judgements rather than faulty calculations'. ${ }^{20}$

18 Hindle, Emulation and Invention, 128.

19 Eugene S. Ferguson, 'How Engineers Lose Touch', American Heritage Invention and Technology 8 (Winter, 1993): 16.

20 Ferguson, 'How Engineers Lose Touch', 20. 
The popular notoriety and adulation once enjoyed by inventors has now, it seems, all but disappeared. By the early 1900s, as the historian Robert Friedel has shown, the popular image of the independent genius inventor was being replaced by a new social type, the 'expert'. ${ }^{21}$ With the steady elaboration of professions, increasing access to higher education and soaring prestige for science, the genius was displaced by the welltrained; likewise, information was privileged over insight, science over experience, numbers over pictures and the rational over the intuitive. The social goals of rationalisation and efficiency changed the ways in which natural resources were exploited (conservation), labour was marshalled (scientific management), and even the way in which technological change was accomplished (industrial research). ${ }^{22}$

The process can be seen clearly in the transformation of the electrical industry in the United States during the last years of the nineteenth century. As independent inventors like Thomas Edison attempted to develop, manufacture and market their new devices, they came to need the talents of business management and salesmanship, as well as large amounts of capital investment. ${ }^{23}$ At the same time, competing inventions made it increasingly difficult to put together the best technical systems and to integrate systems without patent pools or some other form of consolidation.

In this climate, inventors bought each other out, and when they turned to finance capitalists, like J. P. Morgan, the latter provided money only on condition that they have a significant say in the resulting enterprises. The firm of Thomson-Houston, for example, was the result of the merged interests of those two pioneer electrical inventors. Using Morgan money, this firm bought out Edison and changed its name to Edison General Electric, although the world's most famous, and arguably successful inventor, lost control of his inventions in the process. The new giant firm controlled as well the patents of Frank Sprague, the 'father' of American streetcar technology, and Charles Brush, who had developed the nation's first successful arc-lighting system.

21 Friedel, 'Perspiration in Perspective', 16.

22 See Carroll Pursell, 'The Coming of Science and Systems', in The Machine in America: A Social History of Technology, 2nd ed. (Baltimore: Johns Hopkins University Press, 2007).

23 For the role of one inventor in this process see Carroll Pursell, 'Lewis Latimer and the Role of Black Inventors', in Technology in America: A History of Individuals and Ideas, ed. Carroll Pursell, 3rd ed. (Cambridge: MIT Press, 2018), 125-34. 
General Electric, or Edison General Electric as it was originally called, heavy with patents from some of America's most ingenious electrical inventors, had cut those inventors out of the loop, thereby isolating itself from the very wellsprings of its technological advantage. To ensure that funds were spent on production and sales, not simply on endless 'progress', inventors found their freedom severely limited. Most had no desire to become corporate bureaucrats in any case, and went on to invent in other fields. This large corporation then, was left with a market share based on inventions that were likely someday to be replaced-but by what, and invented by whom? The initial strategy was to remain alert to the light bulbs going off over the heads of inventors all over the world, with the intention of buying the resulting patents or at least the American rights to the new devices. It was by definition a chancy and unpredictable business.

In 1900, General Electric established its famous research laboratory in Schenectady, New York. It was to be, in a sense, an organised, rationalised, predictable analogue to the creative geniuses who had made the original inventions upon which the firm's product line was based. The laboratory, in the words of one historian, both reflected and reinforced the:

Modern notion of technical change owing more to institutions and less to individuals, of invention as being the province of corporations and not of wizards, of human minds and knowledge making a difference in the way people live and work and die not through creative brilliance but through organization and control. ${ }^{24}$

It was an institution, perhaps, not entirely unlike the workshops of Renaissance Italian artists or those of early modern Holland.

But progress seems to still need genius as well as expertise. At a critical point in Fritz Lang's classic expressionist film Metropolis, the master of the city visits a half-mad inventor who lives not in one of the shiny skyscrapers of the metropolis but in a tiny wooden dwelling nestled between them, a cottage better suited to the deep woods than the city of the future. The inventor, wild of hair and eye, has one metal hand, to replace the natural one amputated in the course of his work; his humanity had been reduced, and replaced by the very technology that had destroyed it. The master had reached a crisis in his relations with his workers and, he tells the inventor, he has turned to him for help since his 'experts' had failed him.

24 Friedel, 'Perspiration in Perspective', 22. 
Yet, as the neoliberal economists Jewkes, Sawyers and Stillerman pointed out in their 1958 book The Sources of Invention, committees do not invent, people do. In a series of charming case studies of twentiethcentury invention, they show how, time after time, new ideas came from individuals, however necessary large institutions were in getting the ideas through to production and market. ${ }^{25}$ The historian George Wise has usefully pointed out that new ideas came from people positioned along a spectrum, not clustered at the polar opposites of independent genius and corporate bureaucrat:

The 'outside' inventors were more dependent on, and the 'inside' inventors were more independent of, corporate policies and choices than previous accounts have depicted. Their choice of targets, the marshalling of support, the use of resources and information, differed in degree, not in kind. ${ }^{26}$

Even the most 'independent' inventors did contract work for, or sold their ideas to, corporations. At the same time, Wise finds throughout the giant electrical firms 'pockets of invention and innovation', often led by workers who appeared on the official personnel lists as 'shop superintendent', 'consulting engineer', 'mechanical engineer' or under some other job title that did little to reveal their true activities. Such people 'enjoyed the patronage, support, and protection of a high-level executive' and practised what Wise calls 'intrapreneurship': 'playing the role of entrepreneur within the corporation'. ${ }^{27}$

Wise does well to remind us that ideas still have to come from someone, and that the people who have those ideas need the help of others to put them to practical use. But the world of Rube Goldberg, the engineer turned cartoonist-inventor of such devices as that to remove cotton from aspirin bottles and the classic 1942 'Automatic Hitler-Kicking Machine', was gone long before he himself died in $1970 .{ }^{28}$

25 John Jewkes, David Sawers and Richard Stillerman, The Sources of Invention (New York: St Martin's Press, 1958).

26 George Wise, 'Inventors and Corporations in the Maturing Electrical Industry, 1890-1940', in Inventive Minds: Creativity in Technology, ed. Robert J. Weber and David N. Perkins (New York: Oxford University Press, 1992), 293.

27 Wise, 'Inventors and Corporations', 299.

28 Peter C. Marzio, Rube Goldberg: His Life and Work (New York: Harper \& Row, 1973). See also the English cartoonist of 'invention' in W. Heath Robinson, Inventions (London: Gerald Duckworth \& Co., 1973). 
Today, the names of inventors do occasionally come to public attention. The 11 May 2008 edition of the San Francisco Chronicle, for example, carried an obituary of Hugh Brander, a physicist at the University of California (Berkeley) who had worked on the World War II Manhattan Project producing the first atomic bombs. By 1951 he was a consultant for the US Naval Ordinance Laboratory where he developed a wetsuit, made of neoprene, for the use of Navy SEALS. He did not patent it, he later explained, because he thought 'maybe fifty people in the country' would ever use it. A year later the same wetsuit was 'invented' by Jack O'Neill who operated the Surf Shop in San Francisco. ${ }^{29}$ To complicate matters further, in 1953 two brothers who ran the Dive 'N Surf shop at Manhattan Beach invented what they called the 'Body Glove'. ${ }^{30}$ Brander had missed out on the chance to profit from the millions of surfers who would go on to use his invention.

The 'inventor', whether of the wetsuit or steam engine, seems to have largely disappeared from both popular culture and serious literature, despite such celebrated cases as Steve Jobs and Elon Musk. But, if we can no longer easily recite the names and tell the stories of recent inventors, perhaps we can begin to turn to more realistic studies of how and why things change. Or perhaps, even more importantly, we can wean ourselves from the prejudice that it is the design of new technologies, whether by inventors or engineers, that is the most glamorous and important element in the history of technology. Perhaps we can begin to value persistence of design and use as well as change, and the use, servicing and maintenance of machines as well as their design. And, when changes are looked at, we would do well to pay more attention to those introduced through repair and suggested by use. Indeed, the historian David Edgerton has provided a convincing account of the persistence and reintroduction of old technologies in the face of constant novelty. ${ }^{31}$ Perhaps with invention placed in its proper context, we can begin to understand it better.

29 'History of the Wet Suit', accessed 7 July 2019, 360guide.info.wetsuits/wetsuit-history.html (site discontinued).

30 'The Story Behind the Body Glove', DivingHistory.com, accessed 7 July 2019, divinghistory. com/id20.html.

31 David Edgerton, The Shock of the Old: Technology and Global History Since 1900 (New York: Oxford University Press, 2007). 
This text is taken from ANU Historical Journal II: Number 2, published 2020 by ANU Press, The Australian National University, Canberra, Australia.

doi.org/10.22459/ANUHJII.2020.10 